\title{
Ichthyophthiriasis in carp Cyprinus carpio: infectivity of trophonts prematurely exiting both the immune and non-immune host
}

\author{
T. Wahli ${ }^{1, *}$, R. A. Matthews ${ }^{2}$ \\ ${ }^{1}$ Centre for Fish and Wildlife Health, Institute of Animal Pathology, University of Berne, Länggass-Strasse 122, \\ CH-3012 Bern, Switzerland \\ ${ }^{2}$ Department of Biological Sciences, University of Plymouth, Drake Circus, Plymouth PL4 8AA, Devon, United Kingdom
}

\begin{abstract}
Ichthyophthirius multifilis exposed to naturally immunised carp established short-term infections, the majority of parasites actively emerging within $2 \mathrm{~h}$ of entering the epidermis. A small, but significant, number of these expelled parasites were shown to retain theront-like properties with the capacity to directly re-invade a further fish host. Infectivity fell rapidly with time in the host and was comparable to that of trophonts of a similar age artificially induced to emerge from non-immune hosts with the aid of MEM (minimal essential medium). Trophonts recovered with MEM from immune carp 2 to $8 \mathrm{~h}$ post infection rarely established infections upon exposure to susceptible new hosts and no infections resulted from older trophonts recovered after 8 to $24 \mathrm{~h}$ exposure; older trophonts, however, represented only a small percentage of the original parasite population. A low level of infectivity was recorded in trophonts collected with the aid of MEM from non-immune carp after up to $24 \mathrm{~h}$ of infection. The results are discussed in relation to theront transformation and evasion of the host immune response.
\end{abstract}

KEY WORDS: Ichthyophthirius multifiliis · Carp · Infectivity Immune evasion · Premature exit

\section{INTRODUCTION}

The ciliate Ichthyophthirius multifiliis Fouquet invades the epithelia of the skin and gills of a wide variety of freshwater fish in tropical, subtropical and temperate regions (Nigrelli et al. 1976, Valtonen \& Keränen 1981) and accounts for economic losses in cultured freshwater species (Matthews 1994). As early as 1910 Buschkiel reported that fish which had experienced and survived an $I$. multifiliis infection were at least partly resistant to re-infection (Buschkiel 1910). These early findings have since been confirmed by several authors in a wide range of fish (Bauer 1958, Beckert \& Allison 1964, Hines \& Spira 1973, 1974, Dickerson et al. 1984, Wahli \& Meier 1985, Houghton \& Matthews 1986, McCallum 1986, Subasinghe \& Sommerville 1986). Serum from immunised fish was shown

•E-mail: thomas.wahli@itpa.unibe.ch to immobilise parasites in vitro (Hines \& Spira 1974 Wahli \& Meier 1985, Houghton \& Matthews 1986, Clark et al. 1987); however no similar effect has been demonstrated in vivo so far. Hines \& Spira (1974) reported a complete lack of ciliates in the mucus of immune carp. Based on this finding, they suggested that mucus of immune fish has a barrier function directed against I. multifiliis. Cross \& Matthews (1992) demonstrated that theronts exposed to the skin of immune carp penetrated the epidermis in the normal way but re-emerged within $2 \mathrm{~h}$ after penetration without completing development. Monoclonal murine antibodies directed against surface membrane antigens of I. multifiliis immobilised the parasite in vitro. When these antibodies were passively transferred to catfish, no immobilisation was achieved but rapid exit of the parasites from the epithelium resulted (Clark et al. 1996). After exit from the host, parasites appeared viable in all respects although antibodies were detectable on their surface. Matthews et al. (1996) induced 
premature exit of I. multifiliis from hosts by altering the external environment by exposing the fish to Eagle's minimal essential medium (MEM).

The fate of parasites induced to exit the skin prematurely either by the MEM method or by the hosts immune system is not known. The present study aimed (1) to determine whether trophonts prematurely recovered from a non-immune host retain an ability to directly re-infect new hosts or to complete encystment and develop infectious theronts and (2) to assess the viability of 'post theronts' prematurely exiting or induced to exit immune fish.

\section{MATERIALS AND METHODS}

Fish. Juvenile carp Cyprinus carpio L. (2 to $6 \mathrm{~cm}$ length), naive to ichthyophthiriasis, were obtained from the Hampshire College of Agriculture, Sparsholt, UK. These were kept in de-chlorinated tap water at $20 \pm 2^{\circ} \mathrm{C}$ and held in $5 \mathrm{l}$ glass aquaria. Water quality was maintained by aeration, biological filtration and partial water changes. All fish were fed daily on goldfish flakes (King British, Bradford, UK). When necessary, fish were anaesthetised with MS 222 (3-aminobenzoic acid ester, Sigma Chemical Co., St. Louis, USA) at a concentration of $50 \mathrm{mg} \mathrm{t}^{-1}$

Parasite isolate. Ichthyophthirius multifiliis was isolated from rainbow trout Oncorhynchus mykiss L. obtained from a local fish farm on a tributary of the river Erne, Devon. It was routinely maintained through serial primary infections in carp and goldfish Carassius auratus. All procedures concerning handling of parasitic and free-living stages were as previously described by Wahli (1985, p 47-49).

Infection of carp with Ichthyophthirius multifiliis. Isolated tomonts were allowed to encyst in crystallising bowls and were incubated at room temperature (18 to $20^{\circ} \mathrm{C}$ ) for $24 \mathrm{~h}$. In establishing experimental infections, theronts were used within 3 to $4 \mathrm{~h}$ of excystment; viability was tested on naive carp prior to challenge of immune fish. Theronts and trophonts were enumerated either in a $1 \mathrm{ml}$ sample of suspension with the aid of a Sedgewick-Rafter cell on immobilisation by the addition of 1 drop of formalin or by counting the parasites in $24 \times 5 \mu$ l suspension after adding 1 drop of formalin and calculating the mean for $1 \mathrm{ml}$. As results of the 2 methods never differed more than $10 \%$, the faster drop method was preferred.

MEM induced exit of trophonts from infected fish. Premature exit of trophonts from primary infections was induced by immersion of carp in MEM (Eagle's Minimum Essential Medium; Gibco BRL, Life Technologies Ltd., Paisley, Scotland) for $50 \mathrm{~min}$ following the method described by Matthews et al. (1996). Here, however, the effect of the MEM was also investigated at $1: 1$ and $1: 2$ dilutions in distilled water. The number of exiting trophonts was scored as low $<10$ parasites per view at $25 \times$ magnification), medium (10 to 20 parasites per view) or high ( $>20$ parasites per view) respectively.

Immunisation of carp against Ichthyophthirius multifiliis. 60 juvenile carp, 4 to $6 \mathrm{~cm}$ in length were exposed to 5000 theronts fish ${ }^{-1}$ in $250 \mathrm{ml}$ of gently aerated water for $1 \mathrm{~h}$. Following infection, fish were maintained in aquaria and infections allowed to proceed to conclusion. Fish were re-exposed to theronts after $1 \mathrm{mo}$, following clearance of previous infection, and challenged on 3 further occasions, at 10 to $20 \mathrm{~d}$ intervals, with increasing numbers of theronts $(5000$ to $10000 \mathrm{fish}^{-1}$ ). These immunised fish were maintained for a minimum period of $14 \mathrm{~d}$ before use in experiments (Houghton \& Matthews 1986).

Experimental procedure. Primary infections (Fig. 1): 100 carp were infected with Ichthyophthirius multifiliis following exposure to theronts as described above. Two to 4 fish (donors) were removed at timed intervals after exposure, passed through 3 containers of clean water to remove any free theronts from the fish surface, and placed in $7 \mathrm{ml}$ of MEM in glass crystallising bowls for $50 \mathrm{~m}$ to induce trophont emergence. Timed intervals included $1,2,3,4,6,8,10$ and $12 \mathrm{~h}$ and thereafter every $24 \mathrm{~h}$ up to the 6th day of infection. All fish investigated at intervals later than $8 \mathrm{~h}$ post exposure were killed with an overdose of MS222 and immediately washed in clean water prior to treatment with MEM. The number of exiting trophonts was estimated following removal of infected fish from glass containers by a stereomicroscope (25× magnification). The MEM containing the parasites was then diluted by addition of $70 \mathrm{ml}$ of aerated water and a single carp (recipient), naive to I. multifiliis, was introduced to the system for a period of $1 \mathrm{~h}$, providing opportunities for infections to be established by the exited trophonts. After removal of the recipient to a new aquarium any free trophonts remaining within the crystallising bowls were monitored for survival, encystment and ability to complete development with the production of viable theronts. The exposed recipient was maintained in isolation for $5 \mathrm{~d}$ at 19 to $20^{\circ} \mathrm{C}$. The number of white spots detected provided a rough comparison of infection level; these foci might include more than 1 trophont. Spots were scored as follows with respect to infection, in parentheses: $+=1$ to 5 parasites (low), $++=6$ to 10 parasites (moderate) and $+++=>10$ parasites (heavy).

The following procedure was adopted in order to determine the percentage of exiting parasites capable of re-invading another host. 10 carp were exposed individually to Ichthyophthirius multifiliis as described above (infection dose: 22000 theronts fish ${ }^{-1}$ ). After $1 \mathrm{~h}$, 


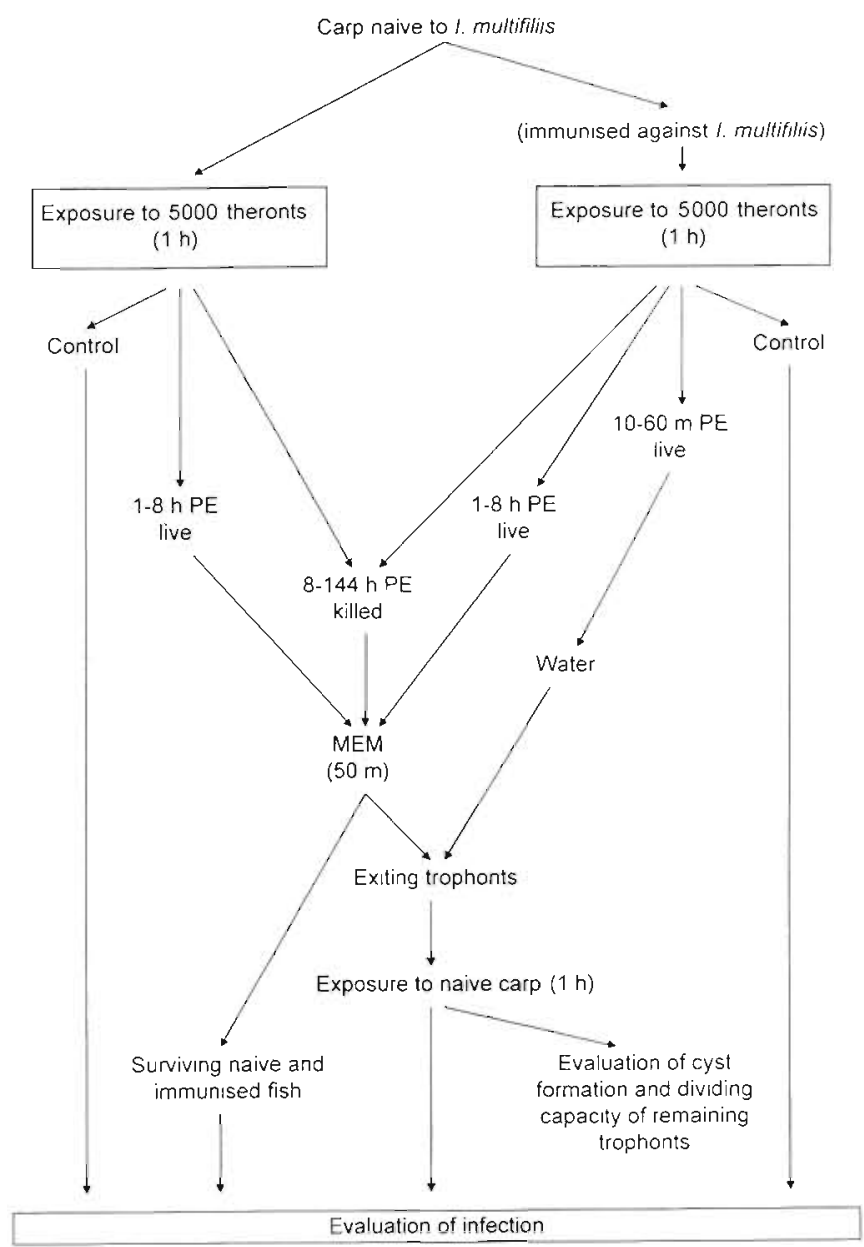

Fig. 1 IChthyophthirius multifilis infecting Cyprinus carpio. Procedure for testing infectivity of prematurely recovered tomonts. PE: post exposure

fish were carefully rinsed 3 times in clean water and transferred to MEM for $50 \mathrm{~min}$. Parasites remaining in the infection bath and in the MEM after removal of fish were counted. Naive fish were exposed to the recovered parasites for $1 \mathrm{~h}$ then transferred to holding tanks. After $5 \mathrm{~d}$ developing parasites on these latter carp were enumerated.

Recovery of trophonts from immunised carp (Fig. 1): 60 carp immunised against Ichthyophthirius multifilis were exposed to theronts for $1 \mathrm{~h}$ as in primary infections above. At known times post exposure (PE), 1 fish was examined for exiting trophonts, these being recovered for viability tests as described for primary infections. Investigations of emerged trophonts up to $1 \mathrm{~h} \mathrm{PE}$, including at intervals of $10,20,30,50$ and $60 \mathrm{~min}$, however, were undertaken on fish maintained in water without the addition of MEM; trophonts are known to exit immunised carp within $2 \mathrm{~h}$ of infection (Cross \& Matthews 1993). Immediately following exposure, these fish were quickly passed through 3 containers of clean water to remove free theronts and finally to $7 \mathrm{ml}$ of water contained in crystallising bowls, from which exiting trophonts were recovered over a 90 min period. Those immunised carp examined at later intervals, 2 , $4,6,8,10$ and $12 \mathrm{~h}$ and daily up to Day 6 post exposure, were maintained in MEM for $50 \mathrm{~min}$, as in primary infections; those examined after $8 \mathrm{~h}$ were killed with an overdose of MS222 prior to treatment. Treatment with MEM aimed to induce the emergence of developing trophonts which might have evaded the immune response. After careful removal of carp, the MEM was diluted by the addition of $70 \mathrm{ml}$ of aerated water and the infectivity of recovered trophonts investigated following the procedure shown in Fig. 1.

\section{RESULTS}

\section{MEM induced exit of trophonts in primary infections with time PE to theronts}

MEM was more effective in stimulating premature exit of trophonts when used at full strength, fewer parasites being recovered at $1: 1$ and $1: 2$ dilution in water. Undiluted MEM was therefore used in all subsequent experiments. No adverse effects were recorded in carp as a result of short-term exposure to MEM as used in the present study and all survived treatment. The highest number of parasites was recovered from live fish sampled within $4 \mathrm{~h}$ PE, the first trophonts exiting immediately upon treatment with the undiluted MEM. Relatively lower yields of trophonts were obtained from fish at $8 \mathrm{~h} \mathrm{PE}$, although recovery was marginally greater from freshly killed fish. However only single parasites left a freshly killed fish within $1 \mathrm{~h}$ when incubated in water whereas clearly more parasites could be recovered from a MEM-incubated dead fish in the same period. Parasites induced to exit up to $8 \mathrm{~h}$ PE still resembled the theront stage in shape, having an elongated body, and in behaviour, actively swimming in the upper water layer. In contrast, those emerging later were spherical, with considerable variation in diameter by $3 \mathrm{~d}$ PE, and tended to settle on the bottom of the container shortly after leaving the fish. Some trophonts recovered after $3 \mathrm{~d}$ PE resembled theronts in size, shape and behaviour. All surviving tish showed a moderate to heavy infection 5 to $6 \mathrm{~d} P E$ even when they had previously been exposed to MEM.

\section{Viability of trophonts following MEM-induced emergence from primary infections}

Trophonts recovered up to $24 \mathrm{~h}$ PE were able to reinfect naive carp, the degree of infectivity decreasing 


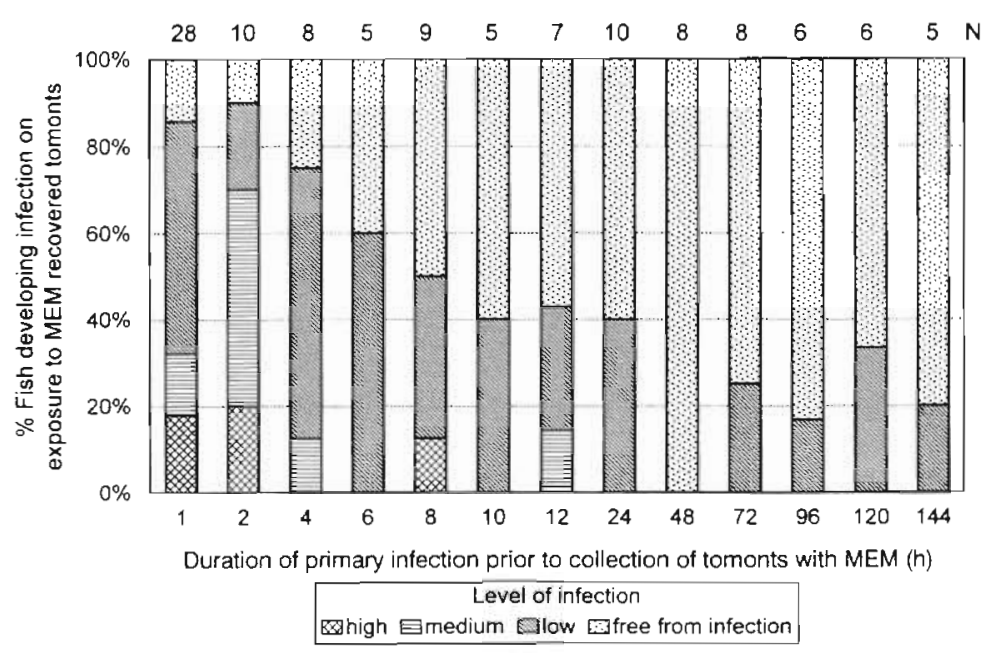

Fig. 2. Ichthyophthirius multifilis infecting Cyprinus carpio. Infection levels of $I$. multifiliis recorded in carp following exposure to tomonts prematurely recovered from a primary infection in carp with the aid of MEM. $N=$ carp exposed at each time interval

with time PE during this period (Fig. 2). No trophonts recovered $48 \mathrm{~h}$ PE were able to re-infect carp directly, However some of these trophonts completed the aquatic phase of development, encysting and producing viable theronts. Parasites exiting after $72 \mathrm{~h} \mathrm{PE}$ and on Days 5 and 6 PE following MEM treatment produced low level infections on re-exposure to naive carp. The few trophonts detected in such cases were significantly smaller compared to those observed in the control carp from the primary infection.

Eighty percent of the theronts exposed to carp in primary infections were estimated to have entered the tissues within the $1 \mathrm{~h}$ exposure period. On treatment with MEM $1 \mathrm{~h} \mathrm{PE}, 11$ to $29 \%$ of these were induced to exit prematurely within 50 min. Infections, although in the low category $(+)$, were established in 8 of the 10 fish exposed to these emerged trophonts. This represented approximately $0.1 \%$ of the original trophonts population of the primary infection (Table 1).

\section{Exit of trophonts from immunised carp with time PE to theronts}

A significant number of trophonts exited the immunised carp within $1 \mathrm{~h}$ PE without MEM treatment. In contrast, only 1 or 2 trophonts emerged from nonimmune control carp exposed to similar numbers of theronts within the same time period. Trophonts could still be recovered from immune carp up to $48 \mathrm{~h}$ PE with the aid of MEM. The appearance of these trophonts was identical to that of corresponding parasites collected from non-immunised fish, although the former showed a more active swimming behaviour. Few parasites emerged after $2 d$, although slight infections confined to the periphery of fins were detected on 1 or 2 carp. Nonimmune controls developed ichthyophthiriasis and some died during the second phase of infection.

\section{Viability of trophonts following premature emergence from immunised carp}

A small number of trophonts recovered up to $8 \mathrm{~h}$ PE were able to re-infect naive carp (Fig. 3). The degree of infection decreased with time PE. Trophonts exiting immunised carp later than $8 \mathrm{~h} \mathrm{PE}$ were not able to reinfect a fish except in one single case in which few parasites recollected $48 \mathrm{~h}$ PE developed to mature trophonts within the fish. Highest infection degrees were found with parasites sampled $1 / 2,1$ and $2 \mathrm{~h}$ after the initial infection.

\section{DISCUSSION}

Although Cross \& Matthews (1992) described the expulsion of Ichthyophthirius multifilis from immune carp, they did not investigate the viability of the exiting parasites. In the present study these are shown to retain theront-like properties for up to $8 \mathrm{~h}$ following the invasion of carp epidermis with the potential, upon premature exit, to re-invade and complete development within a further fish host. The majority of trophonts had actively emerged within $2 \mathrm{~h}$ of infection and parasites remaining within immune hosts after this period and all those from non-immune carp were recovered only with the aid of MEM. Infectivity of trophonts emerging in direct response to immune hosts

Table 1. Ichthyophthirius multifiliis infecting Cyprinus carpio. Fate of $I$. multifilis exposed to carp in primary infections and following induced emergence in MEM 1 h PE. Carp for secondary infection: $\mathrm{N}=15$

\begin{tabular}{|lccc|}
\hline Stage of infection & \multicolumn{3}{c}{$\%$ of initial theront population } \\
& Mean & Minimum & Maximum \\
\hline $\begin{array}{l}\text { Theronts entering carp } \\
\text { at 1st exposure }\end{array}$ & 82.5 & 81.8 & 83.2 \\
$\begin{array}{l}\text { Trophonts recovered } \\
\text { in MEM }\end{array}$ & 19.8 & 11.3 & 29.3 \\
$\begin{array}{l}\text { Trophonts completing } \\
\text { development after } \\
\text { second invasion }\end{array}$ & 0.098 & 0 & 0.55 \\
\hline
\end{tabular}




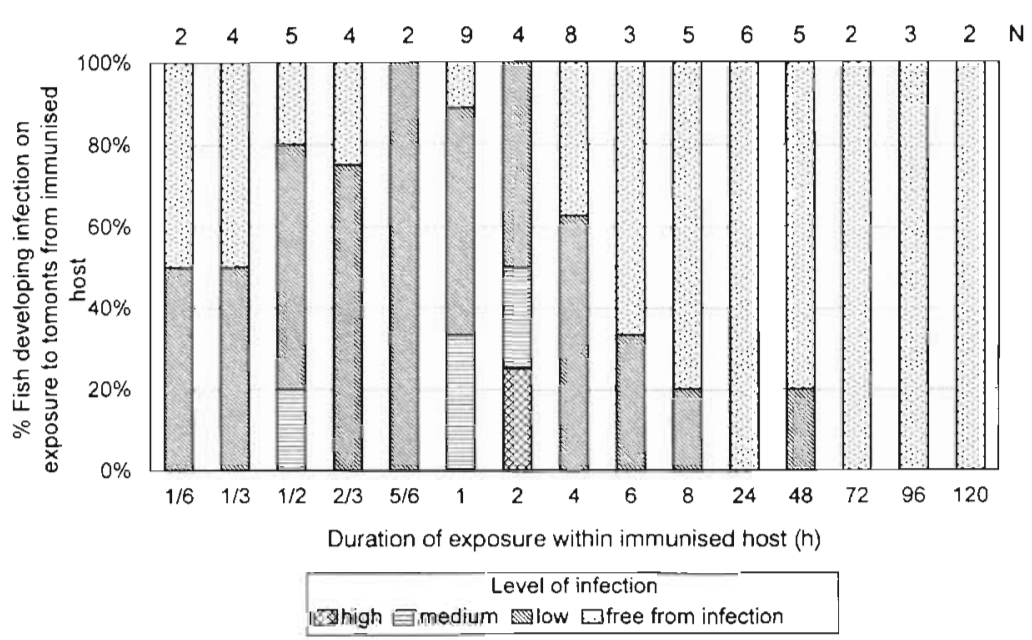

Fig. 3. Ichthyophthirius multifiliis infecting Cyprinus carpio. Infection levels of I. multifiliis recorded in carp following exposure to tomonts prematurely exited from immunized hosts of the same species. Recovery method from primary infected host: within $1 \mathrm{~h}$ post infection active exit, thereafter with the aid of MEM. $\mathrm{N}=$ carp exposed at each time interval

was comparable to that of trophonts of similar age recovered from non-immune carp with MEM although in both groups viability was significantly higher in parasites emerging within $1 \mathrm{~h}$ of infection. That few infections were established by post $2 \mathrm{~h}$ trophonts from immune carp and none by post 8 h trophonts was not unexpected as the majority of the parasite population would already have exited in response to immune factors. Nevertheless viable trophonts were recorded up to $8 \mathrm{~h}$ post infection irrespective of the immune status of the host from which the parasites emerged or whether the emergence was induced by MEM treatment. Previous studies of $I$. multifiliis suggest a commitment to trophont transformation and maturation immediately on host entry, with the sequential release of the theront's secretory products from mucocysts and the organelle of Lieberkühn. Mucocysts are thought to play a major role in the infection process as their discharge coincides with contact and penetration of the host surface (Matthews \& Matthews 1984, Ewing et al. 1985, Ewing \& Kocan 1992). It is possible that depletion of these organelles contributed to the rapid decline in viability of prematurely emerging parasites. Mucocysts are present in all stages of the life cycle of I. multifiliis although the question of whether they are chemically distinct in theronts and trophonts is unresolved. Their reappearance within $5 \mathrm{~h}$ trophonts (Matthews \& Matthews 1984) could account for the infectivity recorded in parasites recovered up to $24 \mathrm{~h}$ PE from non-immune fish. The fact that only a very small number of infections were established from these older parasites, however, is consistent with trophont maturation, including the disappearance of the orga- nelle of Lieberkühn over a time scale of 1 to $18 \mathrm{~h}$ post infection (Matthews et al. 1996). The small number of infective 8 to $24 \mathrm{~h}$ trophonts recovered from nonimmune fish might, therefore, be attributed to slow developers and delayed transformation. There was no evidence of post $24 \mathrm{~h}$ trophonts directly invading new fish hosts, and by $72 \mathrm{~h}$ the parasites could have attained the threshold size for encystment and theront production within the aquatic environment (Maclennon 1937, 1942, Ewing et al. 1986). We suggest that the infections established from post $72 \mathrm{~h}$ trophonts in the present study resulted from such a new generation of theronts.

Recent studies by Clark et al. (1996) and Clark \& Dickerson (1997) indicate the involvement of specific antibodies in triggering premature exit in the immune host,

$3 \mathrm{~d}$ old trophonts being induced to emerge from channel catfish following passive immunisation with monoclonal antibodies (mAb) against surface antigens (i-antigens). The expulsion of trophonts was shown to be dependent upon mAb binding to the ciliary surface at sub-lethal levels as parasite development proceeded normally with the production of theronts on entering water. Results presented in this study support a similar role for antibody in natural immunity against ichthyophthiriasis as theronts both entered and exited the epidermis of immune hosts yet retained the potential to re-infect a further fish host. The ability to respond rapidly to specific components of the immune host ensures a high probability that infectivity will be retained by a significant proportion of the expelled parasite population. Immobilising antibodies are a characteristic feature of the humoral response of fish to Ichthyophthirius multifilis and are known to inactivate both theronts and trophonts in vitro (Wahli \& Meier 1985). The question of whether these play a role in the protection of fish against ichthyophthiriasis has yet to be resolved.

The fact that a small number of trophonts remained within the immune hosts after $2 \mathrm{~h}$ might have resulted from normal healing processes, their escape being impeded by tissue entrapment. In primary infections epidermal regeneration quickly isolates the trophont from the external environment. According to Ewing et al. (1985), gill epithelium regains its normal appearance within 45 min of invasion by Ichthyophthirius multifiliis whereas lger \& Abraham (1990) reported advanced stages of healing in carp epidermis within $3 \mathrm{~h}$ of artificially inflicting wounds. To what extent the survival of $l$. multifiliis is affected by prolonged exposure 
to specific components of the immune response is far from clear as live trophonts were recovered here from immune hosts after $2 \mathrm{~d}$ following the MEM treatment. Houghton \& Matthews (1993) have also described the survival of this parasite in immune carp for up to $3 \mathrm{~d}$. Following administration of the synthetic corticosteroid triamcinolone acetonide, trophonts developed to completion on the immune host, revealing that the cell-mediated immune response was suppressed. Matthews (1994) suggested that evasion of host response might be attributed to the trophont's ability to modify its immediate environment by destruction and phagocytosis of host cells. In the light of recent studies by Clark et al. (1996) localised antibody depletion resulting from antigen saturation of the epidermis might also account for the survival of small numbers of trophonts within the immune host. The fact that parasite numbers dwindled with day of infection and ciliates could not be detected in most immune hosts after 4 d both here and by Houghton \& Matthews (1993) could also be explained on the basis of recovering antibody levels within the epidermis. That surviving parasites represent latent stages seems unlikely as trophont growth and development did not appear to be compromised within the immune host in the present study although those recovered after $2 \mathrm{~d}$ PE had not reached a sufficient stage of maturity for further development in the aquatic environment. Nevertheless, the presence of such concealed parasites would be significant in the transmission of ichthyophthiriasis in stressed fish populations. The small number of trophonts developing full-time infections within the peripheral regions of the fins of immunised carp here was probably indicative of a decline in the protective response (Houghton \& Matthews 1993)

How MEM induces premature exit of Ichthyophthirius multifiliis was not investigated; however, it seems possible that osmotic factors are involved because full strength medium, as recommended by Matthews et al. (1996), was most effective in recovering parasites from the fish epithelium. It is assumed that MEM, being iso-osmotic with the fish epithelium, might equalise the concentration between host and aquatic environment, permitting the highly motile trophonts to freely move between the two. In support of this view, only a limited proportion of the parasite population was recovered in MEM and success was greatest within $4 \mathrm{~h}$ of infection when trophonts might still have been in contact with the exterior via entry routes prior to epidermal regeneration (Iger \& Abraham 1990). Such artificial means of inducing emergence may not be comparable to normal events within the host. Nevertheless, it may be relevant that Ewing \& Kocan (1992) suggested that the pressure of fluid expulsions from contractile vacuoles might aid in the normal escape of this parasite from host tissues whereas excretion of tissue hydrolases from these organelles has also been suggested by Clark \& Dickerson (1997). The fact that percent recovery diminished with time in the host suggests that trophonts become decreasingly attracted to high osmolarities with maturation, such that exit is assured in the tomont. Modulation of a response to osmolarity with parasite growth could provide a simplistic explanation for the behaviour observed in 1 . multifiliis. Ciliates are known to respond to a wide variety of environmental stimuli, behavioural responses being mediated through membrane bound receptors (Machemer \& Dietmer 1987, Lukas et al. 1989). The temporary occlusion of such receptors by antigen antibody complexes at the cell surface could possibly account for the premature emergence of $I$. multifiliis from the immune host.

Acknowledgements. The authors wish to thank Dr Ben Matthews for her invaluable assistance in this research and Stan McMahon and Richard Ticehurst for their assistance in fish keeping. This work was supported by a grant from the CIBA-GEIGY Jubilaeumsstiftung to T.W.

\section{LITERATURE CITED}

Bauer ON (1958) Biologie und Bekämpfung von Ichthyophthirius multifiliis Fouquet. Z Fisch Hilfswiss 7:575-581

Beckert H, Allison R (1964) Some host response of white catfish to Ichthyophthirius multifiliis Fouquet. Proc SE Assoc Game Fish Comm 18:438-441

Buschkiel AL (1910) Beiträge zur Kenntnis des Ichthyophthirius multifiliis. Arch Protistenkd 21:61-102

Clark TG, Dickerson HW, Gratzek JB. Findley RC (1987) In vitro response of Ichthyophthirius multifiliss to sera from immune channel catfish. J Fish Biol 31:203-208

Clark TG, Lin TL, Dickerson. HW (1996) Surface antigen cross-linking triggers forced exit of a protozoan parasite from ist host. Proc Natl Acad Sci. USA 93:6825-6829

Clark TG, Dickerson HW (1997) Antibody-mediated effects on parasite behaviour evidence of a novel mechanism of immunity against a parasitic protist. Parasitol Today 13: $477-480$

Cross ML, Matthews RA (1992) Ichthyophthiriasis in carp, Cyprinus carpio L.: fate of parasites in immunised fish. J Fish Dis 15:497-507

Cross ML. Matthews RA (1993) Localized leucocyte response to Ichthyophthirius multifilis establishment in immune carp Cyprinus carpio L. Vet Immunol Immunopathol 38: 341-358

Dickerson HW, Brown J, Dawe DL, Gratzek JB (1984) Tetrahymena pyriformis as a protective antigen against Ichthyophthirius multifiliis infection: comparisons between isolates and ciliary preparation. J Fish Biol 24:523-529

Ewing MS, Kocan KM (1992) Invasion and development strategies of Ichthyophthirius multifilis, a parasitic ciliate of fish. Parasitol Today 8:204-208

Ewing MS, Kocan KM, Ewing SA (1985) Ichthyophthirius multifilis (Ciliophora) invasion of gill epithelium. J Protozool 32:305-310

Ewing MS, Lynn ME, Ewing SA (1986) Critical periods in 
development of Ichthyophthirius multifiliss (Ciliophora) populations. J Protozool 33:388-391

Hines RS, Spira DT (1973) Ichthyophthirius multufilis Fouquet in the mirror carp Cyprinus carpio L. I. Course of infection. J Fish Biol 5:385-392

Hines RS, Spira DT (1974) lchthyophthiriasis in the mirror carp Cyprinus carpio L. V. Acquired immunity. J Fish Biol 6:373-378

Houghton G, Matthews RA (1986) Immunosuppression of carp (Cyprinus carpio L.) to ichthyophthiriasis using the corticosteroid triamcinolone acetonide. Vet Irmmunol Immunopathol 12:413-419

Houghton G, Matthews RA (1993) Ichthyophthirius multifilis (Fouquet): survival within immune juvenile carp, Cургіnus carpio L. Fish Shellfish Immunol 3:157-166

Iger Y, Abraham $M$ (1990) The process of skin healing in experimentally wounded carp. J Fish Biol 36:421-437

Lukas TJ, Wallen-Friedman M. Kung C, Watterson DM (1989) In vivo mutations of calmodulin: a mutant Paramecium with altered ion current regulation has an isoleucine-tothreonine change at residue 136 and altered methylation state at lysine residue 115. Proc Natl Acad Sci USA 86: $7331-7335$

Machemer H, Dietmer JW (1987) From structure to behaviour: Stylonchia as a model system for cellular physiology. In: Corliss JO, Patterson DJ (eds) Progress in protistology, Vol 2. Biopress Ltd, Bristol, p 213-330

Maclennon RF (1937) Growth in the ciliate Ichthyophthirius. I. Maturity and encystment. J Exp Zool 76:423-440

Maclennon RF (1942) Growth in the ciliate Ichthyophthirius. II. Volume. J Exp Zool 91:1-13

Editorial responsibility: Wolfgang Körting,

Hannover, Germany
Matthews RA (1994) Ichthyophthirius multifiliis Fouquet, 1876: infection and protective response within the fish host. In: Pike AW, Lewis JW (eds) Parasitic diseases of fish Samara Publishing Ltd, Tresaith, p 17-42

Matthews RA, Matthews BF (1984) Ichthyophthinus multifliis Fouquet in juvenile carp: the infection process. Parasitology 89:33

Matthews RA, Matthews BF, Ekless L (1996) Ichthyophthirius multifilis (Fouquet): observations on the life-cycle and indications of a possible sexual phase. Folia Parasitol 43: 203-208

McCallum HI (1986) Acquired resistance of black mollies Poecilia latipinna to infection by Ichthyophthirius multifiliis. Parasitology 93:251-261

Nigrelli RF, Pokorny KS, Ruggieri GD (1976) Notes on Ichthyophthirius multifiliis, a ciliate parasitic on freshwater fishes, with some remarks on possible physiological races and species. Trans Am Microsc Soc 95:607-613

Subasinghe RP, Sommerville C (1986) Acquired immunity of Oreochromis mossambicus to the ciliate ectoparasite Ichthyophthirius multifilis Fouquet. In: Maclean JL, Dizon LB, Hosillos IV (eds) The first Asian fisheries for um. Asian Fisheries Society, Manila, p 279-282

Valtonen ET, Keränen A (1981) Ichthyophthiriasis of Atlantic salmon, Salmo salar L. at the Montta Hatchery in northern Finland in 1978-1979. J Fish Dis 4:405-411

Wahli T (1985) Ichthyophthiriasis bei der Forelle (Salmo sp.) PhD thesis, University of Basle

Wahli T, Meier W (1985) Ichthyophthiriasis in trout: investigations of natural defence mechanisms. In: Ellis A (ed) Fish and shellfish pathology. Academic Press, London, p 347-352

Submitted: September 8, 1998, Accepted: January 1, 1999

Proofs received from author(s): May 17, 1999 